\title{
EURODAC AS AN INSTRUMENT OF THE EU RETURN POLICY ${ }^{1}$
}

\section{Katarzyna Strąk*}

Key words: EU Return Policy, Eurodac Regulation, Dublin System, Refugee Crisis

Abstract: The proposed recast Eurodac Regulation of 2016 extends its previous scope so that both illegally residing third-country nationals and those who have entered the EU irregularly at its external borders could be identified and so that this information could be used by Member States to re-document them for return purposes. In this way Eurodac will, according to the European Commission, contribute to the fight against irregular migration. The proposal is meant to improve the effectiveness of the EU return policy by facilitating the identification of persons illegally on the territory of the EU. After it is adopted, the new Eurodac Regulation may be considered as an example of a flanking instrument of the EU return policy. It should be emphasised that on the one hand the provisions foreseen in the Regulation are highly valuable when it comes to ensuring the effectiveness of the EU return policy. On the other hand, however, it is still unknown what effects it will bring when adopted.

1 This paper was written as part of the research project: "Polityka Unii Europejskiej w zakresie powrotów. Aspekty prawne" (Return Policy of the European Union. Legal Aspects) financed by the National Science Centre, Poland, pursuant to Decision DEC-2012/07/N/HS5/01717.

* Katarzyna Strąk, Institute of Law Studies Polish Academy of Sciences. 


\section{Introduction}

The proposed recast Eurodac Regulation ${ }^{2}$ extends its previous scope so that both illegally residing third-country nationals and those who have entered the EU irregularly at its external borders could be identified and so that this information could be used by a Member States to redocument them for return purposes. In this way Eurodac will, according to the European Commission, contribute to the fight against irregular migration.

The proposal is meant to improve the effectiveness of the EU return policy. According to the European Commission, "facilitating the identification of illegally staying third-country nationals or stateless persons through the use of biometrics would contribute to improve the effectiveness of the EU return policy, notably in relation to irregular migrants who use deceptive means to avoid their identification and to frustrate re-documentation."

Indeed, the refugee ${ }^{4}$ crisis of 2015 has negatively influenced the foundations of the EU return policy, namely and mainly Directive 2008/115 (the so-called Return Directive) and the case-law of the European Court of Justice which is built upon it. In view of extremely different practices that Member States adopted in 2015-2018, it is difficult to ascertain whether the procedures and standards established by the Directive are still

2 Proposal for a Regulation of the European Parliament and of the Council on the establishment of 'Eurodac' for the comparison of fingerprints for the effective application of [Regulation (EU) No. 604/2013 establishing the criteria and mechanisms for determining the Member State responsible for examining an application for international protection lodged in a Member States by a third-country national or a stateless person], for identifying an illegally residing third-country national or stateless person, and on requests for the comparison with Eurodac data by Member States' law enforcement authorities and Europol for law enforcement purposes (recast), COM(2016)272 of 4.5.2016.

3 Proposal..., p. 3.

4 The author of this paper is of the opinion that the term "refugee crisis" is more appropiate than the term "migration crisis", mainly due to the fact that most people arriving in Member States applied for international protection. Compare with Vincent Chetail who also prefers the term "refugee crisis" as "most third-country nationals coming to the EU are asylum seekers or refugees and not economic migrants". See: V. Chetail, Looking Beyond the Rhetoric of the Refugee Crisis: The Failed Reform of the Common European Asylum System, "European Journal of Human Rights” 2016, no5, at pp. 584-585. 
correctly applied. Moreover, identification and re-documentation of thirdcountry nationals has always been a weakness of the EU return policy. The same relates to entering entry bans into the SIS.

After it is adopted, the new Eurodac Regulation may be considered an example of a "flanking measure" instrument of the EU return policy. It should be emphasised that on the one hand the provisions foreseen in the Regulation are extremely valuable when it comes to ensuring the effectiveness of the EU return policy. On the other hand, however, it is still unknown what effects it will bring when it is adopted.

The aim of this contribution is to examine the Eurodac Regulation proposal in light of the EU return policy as a whole and Directive 2008/115 in particular. It is also important to examine whether the "return provisions" of the Regulation are able to influence, whether negatively or positively, the rights of asylum seekers and of other groups covered. It seems at first sight that they are aimed directly against persons who entered the territory of the EU in an uncontrollable way (e.g. the Balkan route) in the first months of the refugee crisis of 2015.

\section{EU return policy and its relations with EU asylum policy}

Before the refugee crisis of 2015 the return policy was defined as an integral and necessary part of a comprehensive EU migration policy. It was argued that when effectively implemented and credible, the return policy remained in no contradiction to a more open migration policy, even allowing the EU to more properly carry out its legal migration policy, labour migration included. An emphasis was placed on the establishment of a virtually effective EU return policy by means of various activities, and in the first place by the adoption of various legal instruments. This approach changed after the outbreak of the 2015 crisis. From then on, and specifically from the adoption of the Agenda for Migration on 13.05.2015, the EU is undertaking action which could be summarised as follows: the aim of the EU in the framework of the Area of Freedom, Security and Justice is to protect those who virtually need international protection and to effectively return those who have no right to stay. The shift has been thus made to connect, more strictly as before, the EU return policy with the asylum and border policies. An exhaustive definition of the notion of "effectiveness" has been constantly built up by European institutions, the Commission and Council, since the end of the twentieth 
century in their political documents (the Commission's communications and the Council's work programmes), however, these were specific legal instruments (Directive 2008/115 on common standards and procedures in Member States for returning illegally residing third-country nationals ${ }^{5}$ ) and the accompanying case-law of the European Court of Justice (ECJ) that led to the establishment of the notion of "the effectiveness of the EU return policy". It must be stressed that the refugee crisis did not have a wider impact on the understanding of that notion's content. What evidently changed were the measures to be adopted to achieve the effectiveness of the EU return policy.

In the Author's opinion, the core of the EU return policy is Article 6 of Directive 2008/115 which establishes a general rule according to which Member States shall issue a return decision to any third-country national residing illegally on their territory, without prejudice to the exceptions referred to in paragraphs 2 to 5 . In other words, a third-country national staying illegally in principle has to leave. When we compare the general rule set in paragraph 1 and the exceptions in paragraphs 2 to 5 , we come to the conclusion that Member States are not obliged to issue a return decision in each case. However, at the same time, the objective of the Union (the effectiveness of the return policy) requires Member States to ensure that persons who do not possess title to stay legally, are not present on the territory of Member States. In view of the above, the purpose of this provision is to terminate the illegal stay of the person concerned in the sense that a third-country national staying illegally either leaves the territory of a Member State or is granted legal title to stay within that territory.

It follows from the foregoing that the EU return policy will in general be assessed as effective when the number of return decisions issued by Member States equals the number of third-country nationals who actually and permanently leave the territory of those states. However, the full effectiveness of the EU return policy is achieved only when the persons staying illegally in principle leave the territory of the whole EU and not only the Member State that issued the return decision, and moreover their departure must be permanent and without delay, in compliance with the return procedures laid down in Directive 2008/115 and with full respect for the fundamental rights of the persons returned.

5 Directive 2008/115/EC of the European Parliament and of the Council of 16 December 2008 on common standards and procedures in Member States for returning illegally staying third-country nationals, O.J. L 348, 24.12.2008, p. 98-107. 
Both the concept and the scope of "the return procedure" are key elements in assessing the effectiveness of the EU return policy in a legal sense. The return procedure was first summarised in C-61/11 PPU El Dridi ${ }^{6}$. It has two stages. The first stage, Article 6, paragraph 1 requires the Member State to issue the return decision against any third-country national illegally present on its territory. At this stage priority is given to voluntary compliance with the obligation resulting from the return decision to leave that territory, subject to Article 7, paragraph 1 which provides that the return decision must provide for an appropriate period for voluntary departure of between seven and thirty days. Article 7, paragraph 1 is a rule, however, where there is a risk of absconding or where an application for legal stay has been dismissed as manifestly unfounded or fraudulent, or where the person concerned poses a risk to public policy, public security or national security, Member States, in accordance with Article 7, paragraph 4, may grant a period shorter than seven days or even refrain from granting a period for voluntary departure. At the second stage, if no period for voluntary departure has been granted, or if the obligation to return has not been complied with within the period for voluntary departure, Article 8 obliges the Member State, in order to ensure the effectiveness of the return procedure, to enforce the return decision and even to carry out the removal of a person who resists removal, and to this end to take all necessary measures, including, where appropriate, coercive measures, which must be used proportionately and with due respect for the fundamental rights of the addressee of the return decision. Removal should be carried out with the use of the least coercive measures possible. However, if the conduct of the third-country national concerned, in light of an assessment of each specific situation, may adversely affect the removal, the Member State may deprive that person of liberty and detain them. To this end Article 15, paragraph 1 provides for the possibility to detain a person only to prepare the return and/or carry out the removal process in particular when there is a risk of absconding or when the person concerned avoids or hampers the preparation of the return or removal process. The deprivation of liberty must be for as short a period as possible and only for as long as removal arrangements are in progress. It is also subject to review at reasonable intervals of time and should be terminated when it appears that a reasonable prospect of removal no longer exists. According to Article 15,

6 Hassen El Dridi, Case no 61/11 PPU, Judgment of 28.4. 2011, ECLI:EU:C:2011:268, at paras. $34-41$. 
paragraphs 5 to 6 read together the period of detention may not exceed eighteen months. The Directive thus fixes the order in which the various successive stages of the return procedure should take place and in this way establishes a gradation of measures to be taken in order to enforce a return decision. The measure which allows the person concerned the most liberty is the granting of a period for voluntary departure, while the most restrictive measure is detention in a specialised facility. The Directive also implies the obligation of Member States to comply with the principle of proportionality throughout all stages of the return procedure.

However, when it comes to the comparison of the number of return decisions issued and the number of returns effected, the situation is far from perfect. For the years 2014-2015-2016, the ratio between the number of persons issued with return decisions and the number of persons effectively returned (voluntary and forced returns) amounted to a mere $41.75 \%-36.78 \%-45.80 \%$, respectively ${ }^{7}$. This is exactly why the improvement of the return rate of third-country nationals issued with return decisions has always been the greatest concern, and especially during the refugee crisis of 2015.

When it comes to describing the relations between the EU return policy and the EU asylum policy, or strictly speaking the return procedure and the asylum procedure, the general rule arising from Directive 2008/115 is that the return procedure is separate from the procedure for granting international protection. Recital nine of the preamble to the Directive bears attention in this regard. It states that a third-country national who has applied for asylum in a Member State should not be regarded as staying illegally in the territory of that Member State until a negative decision on the application, or a decision ending his or her right of stay as asylum seeker, has entered into force ${ }^{8}$. In other words, Directive 2008/115 is not

7 Annex 5 to the Report from the Commission to the European Parliament and the Council - Progress Report on the European Agenda on Migration - Returns, $\operatorname{COM}(2017) 669$ final, 15.11.2017. As for the return ratio for 2010-2011-2012 (36.85\%$34.01 \%-36.77 \%$ respectively) see Communication from the Commission to the Council and the European Parliament - On EU Return Policy, COM(2014)199 final, 28.3.2014.

8 At the time of the adoption of directive 2008/115, this rule arose from Directive 2005/85 (the so-called procedural directive), repealed as of 21.7.2015 by Directive 2013/32/EU of the European Parliament and of the Council of 26 June 2013 on common procedures for granting and withdrawing international protection, O.J. L 180, 29.6.2013, p. 60-95. 
applicable during the procedure in which an application for international protection is examined.

Such a point of view is still reflected in the ECJ case-law. The cases that follow concern third-country nationals who, while in the return procedure (administrative detention), made an aplication for international protection.

In Arslan ${ }^{9}$, handed down in 2013, the Court held that Directive 2008/115 does not apply to third-country nationals who have applied for international protection in the meaning of the (procedural) Directive during the period from making the application to the adoption of the decision at the first instance on that application or, as the case may be, until the outcome of any action brought against that decision is known. Such third-country nationals are entitled to remain in the territory of the Member State concerned at least until their application has been rejected in the first instance and cannot be considered as "staying illegally".

In Kadzoev ${ }^{10}$, the judgment handed down in 2009, the Court said that detention for the purpose of removal and detention of an asylum seeker and the applicable national provisions fall under different legal rules. In consequence, the period during which a person has been held in detention on the basis of the decision taken pursuant to the asylum provisions may not be regarded as detention for the purpose of removal in the meaning of the Return Directive.

In $J N^{11}$, in the judgment delivered in 2016, the Court held that the introduction of an asylum application by a person subjected to a return decision automatically causes all return decisions to lapse. However, the procedure opened under Directive 2008/115, in the context of which a return decision, accompanied, as the case may be, by an entry ban, has been adopted, must be resumed at the stage at which it was interrupted, as soon as the application for international protection which interrupted it has been rejected in the first instance. The effectiveness of the return policy would be endangered if the return procedure could not be resumed at the stage at which it was interrupted but had to start afresh.

9 Mehmet Arslan v. Policie CR, Krajske reditelstvi policie Usteckeho kraje, odbor cizinecke policie, Case no 534/11, Judgment of 30.5.2013, ECLI:EU:C:2013:343, at para. 48.

10 Said Shamilovich Kadzoev (Huchbarov), Case no 357/09 PPU, Judgment of 30.11.2009, ECLI:EU:C:2009:741, at 45 and 48. The same in Arslan, at para. 52.

11 J.N. v. Staatssecretaris voor Veiligheid en Justitie, Case no 601/15 PPU, Judgment of 15.2.2016, ECLI:EU:C:2016:84, at paras. 75-76. 
In a recent judgment delivered on 19 June 2018 in the Gnandi case ${ }^{12}$, the Court held that the return decision may be adopted to a person who applied for international protection, immediately after the rejection of that application and thus before the conclusion of any appeal proceedings brought against that rejection. However, a Member State must ensure that all the legal effects of the return decision are suspended, pending the outcome of the appeal, that the applicant is entitled to the benefits from the (reception) Directive and that he or she is entitled to rely on any change in circumstances that occurred after the adoption of the return decision which may have a significant bearing on the assessment of his or her situation under Directive 2008/115.

\section{Recast Eurodac regulation}

Eurodac was first adopted in 2000 and has since been used for the effective application of the Dublin regulation ${ }^{13}$, at the same time experiencing a series of significant changes as for its objectives, bodies allowed to check the data and groups of persons covered ${ }^{14}$. As for today it contains biometric data, the fingerprints of persons of at least 14 years of age who applied for international protection in one EU Member State, which can be compared with fingerprints sent for comparison by other

12 Sadikou Gnandi v. Etat belge, Case no181/16, Judgment of 19.6.2018, ECLI:EU:C:2018:465.

13 Regulation (EU) No. 604/2013 of the European Parliament and of the Council of 26 June 2013 establishing the criteria and mechanisms for determining the Member State responsible for examining an application for international protection lodged in a Member States by a third-country national or stateless person, O.J. L 180, 29.6.2013, p. 31-59.

14 Compare the original regulation of 2000 (Council Regulation (EC) No. 2725/2000 of 11 December 2000 concerning the establishment of "Eurodac" for the comparison of fingerprints for the effective application of the Dublin Convention) and its recast version of 2013 (Regulation (EU) No. 603/2013 of the European Parliament and of the Council of 26 June 2013 on the establishment of "Eurodac" for the comparison of fingerprints for the effective application of [Dublin Regulation] and on requests for the comparison with Eurodac data by Member States' law enforcement authorities and Europol for law enforcement purposes, and amending Regulation (EU) No. 1077/2011 establishing a European Agency for the operational management of large-scale IT systems in the area of freedom, security and justice). 
Member States and fingerprints of persons apprehended at external borders that are compared with fingerprints of applicants for asylum only. A hit, the presence of the data in the database, is evidence that the person had already been present on the territory of one Member State before they travelled to another Member State.

The amended 2016 Eurodac Regulation proposal foresees that after it is adopted, it will contain biometric data of three groups of persons: applicants for international protection and persons apprehended in connection with an irregular crossing of external borders, both groups already covered by the regulation, and, which is a novelty, persons residing illegally in Member States. Not only the fingerprints but also the facial images of persons of at least six years of age will be recorded from that moment on. Generally speaking, amendments introduced to Eurodac had to first and foremost reflect changes planned in the Dublin regulation and also contribute to the fight against illegal immigration.

Due to the fact that this paper focuses on Eurodac in the light of the EU return policy, only the relevant provisions will be discussed here.

The 2016 proposal introduces a new objective to Article 1. According to Paragraph 1 (b), the new objective of the database will be "to assist with the control of illegal immigration and secondary movements within the Union and with the identification of illegally staying third-country nationals for determining the appropriate measures to be taken by Member States, including removal and repatriation, of persons residing without authorisation."

After that, new provisions aiming at achieving the above objective follow. So new Article 14 obliges Member States to promptly take all a person's fingerprints and to capture a facial image of persons of at least 6 years of age no later than 72 hours after the date of apprehension in order to transmit this information to the central database as well as other personal data relating to the person apprehended ${ }^{15}$. The fingerprint and facial image data of these persons will be automatically compared with the fingerprint and facial image data transmitted by that and other Member States and already stored in the central system, although the comparison of fingerprints will take precedence over the comparison of facial images and the latter will only be compared, as a last resort, when the conditions of the fingertips are inappropriate for an effective comparison or when the person concerned

15 Article 14 paras. 1 and 2. 
refuses to comply with the fingerprinting process ${ }^{16}$. A hit or negative result of the comparison will then be automatically transmitted by the central system to the Member State ${ }^{17}$. Finally, where the person concerned whose data was recorded in Eurodac has left the territory of the Member States in compliance with a return decision or a removal order, the Member State of origin updates its data set by adding the date of that person's removal or when they left the territory ${ }^{18}$.

It is also important to stress that the proposal establishes the order of precedence of the procedures to be applied because where evidence from the central system of a hit in the context of the Dublin regulation is received along with evidence of a hit in the context of an illegal stay, that first evidence always takes precedence over any other hits received ${ }^{19}$ which means that the legal situation of the person concerned will always be examined in the light of Article 1 paragraph 1 letter a).

The Eurodac Regulation proposal sets up the periods of the data storage for each of the groups of persons concerned. The period for the storage of data of persons seeking international protection remains unchanged in comparison to the regulation currently in force. However, the relevant period for persons apprehended at the external borders has been significantly prolonged (from 18 months to 5 years) and the data of persons staying illegally will also be stored for a period of 5 years. This has its justification, according to the European Commission in the fact that the periods for data storage must be in line with the periods of entry bans as set up in the Return Directive.

Last but not least, the already existing Article 37 sets up a general prohibition to transfer data collected in the Eurodac database to third countries, international organisations or private entities. However, the newly incorporated Article 38 introduces an exception from that rule by allowing such transfers to third countries for purposes of return - namely in order to prove the identity of third-country nationals for the purpose of return and only where certain conditions are satisfied. Firstly, the third country must explicitly agree to use the data only for the purpose for which they were provided and to what is lawful and necessary to secure the purpose of return and to agree to delete that data where it is no longer

Article 14 para. 3 in relation with Article 15 and 16.

Article 15 para. 3.

Article 14 para. 6.

Article 15 para. 4. 
justified to keep it. Secondly, the Member State of origin which input the data has given its consent and the person concerned has been informed that his or her personal information may be shared with the authorities of a third-country ${ }^{20}$.

\section{Conclusions}

After a thorough analysis of both the provisions of the proposal and the explanatory memorandum the conclusion should be drawn that the proposal extends the scope of the instrument which for the present moment is solely an asylum database created to ensure the procedures of determining the Member State responsible for the examination of an application for international protection, in accordance with Regulation 604/2013, within the Dublin system. As has already been mentioned, Eurodac can only compare fingerprint data with data in the context of asylum. With the extension of the scope for return purposes, Eurodac will evolve towards becoming a database for wider immigration purposes. The final version of the regulation has not yet been adopted and we still do not know what the final outcome will be. It is true, on one hand, that the European Parliament managed to introduce several amendments to the original European Commission proposal, which aims at improving the legal position of the third-country nationals concerned. To counter any possible negative consequences of Article 38, the European Parliament proposed to introduce an amendment which prohibits the transfer of personal data to third-country nationals if there is a risk that the person concerned may be subjected to torture, inhuman and degrading treatment or any violation of their fundamental rights ${ }^{21}$. It is also true however that, on the other hand, both the Council and the European Parliament consider making sanctions for non-compliance with the fingerprinting process obligatory. It should however be highlighted that in the opinion of the author of this paper, as far as the effectiveness of the EU return policy is concerned, at least the justification of the new objective to be introduced to Eurodac is sufficiently reasonable and coherent, in particular in the context of the recent refugee crisis. This is why it also fits in with

20 Article 38 para. 1 letters b) and c).

21 Article 38 para. 1 letter a). 
recent developments in the area of Freedom, Security and Justice, which will be discussed later.

The principal addressees of the proposal remain nonetheless Member States, first and foremost those not situated on external borders. In the European Commission's view it began to be extremely important during the escalation of the refugee crisis for those countries to store and compare information on persons staying illegally when they did not apply for international protection or did not declare themselves at designated border crossing points when crossing external borders (as has been mentioned, Eurodac registered mainly asylum seekers while recently adopted, although not fully operational at the moment, Entry/ Exit System ${ }^{22}$ will register persons who entered the EU legally but whose visa validity has expired). The central idea is that when already the scope is extended, the information obtained as a result of comparing the data will help Member States to identify the persons staying illegally, to re-document them and even to provide the necessary elements to establish the country through which the individual entered the EU, which will considerably increase the prospect of return.

The European Commission highlights a series of advantages that the proposal offers. Access to biometric data stored in Eurodac of persons staying illegally will thus bring positive effects when it comes to the improvement of the effectiveness of the EU return policy, by accelerating the procedures for the identification and re-documentation of persons, by reducing the length of necessary return and readmission ${ }^{23}$ procedures and facilitation thereof, and by reducing the period of administrative detention. More specifically, it will make easier a more accurate individual assessment of the situation of third-country nationals in the context of examining the risk of absconding and will bring the period

22 Regulation (EU) 2017/2226 of the European Parliament and of the Council of 30 November 2017 establishing an Entry/Exit System (EES) to register entry and exit data and refusal of entry data of third-country nationals crossing the external borders of Member States and determining the conditions for access to the EES for law enforcement purposes, and amending the convention implementing the Schengen Agreement and Regulations (EC) No. 767/2008 and (EU) No. 1077/2011, O.J. L 327, 9.12.2017, p. 20.

${ }^{23}$ Within the EU readmission consists of the procedures of taking back persons staying illegally, after the return decision has been issued, in the framework of cooperation between administrations of EU member States and non-EU countries that concluded a relevant agreement on readmission. 
of data storage in line with the period of entry bans. Apart from enabling the easier identification of persons by the Member States themselves, the proposal offers the tools for cooperation with third countries to share information on particular individuals to obtain travel documents. Last but not least, the proposal aims at enabling interoperability with other information systems.

Some of the above need wider analysis.

By stating that there exists the risk of absconding, the national authorities can decide to restrain the person's liberty and put such a person in administrative detention. The risk of absconding is defined as the existence of reasons in an individual case which are based on objective criteria defined by law to believe that a third-country national who is subject to a return procedure (Return Directive) or a transfer procedure (Dublin Regulation) may abscond. In general, Member States tend to apply it in a discretionary manner although some of the elements of the definition have been recently clarified by the Court of Justice.

An entry ban is an administrative or judicial decision prohibiting entry and stay in a Member State for a specific period, not exceeding 5 years, and it accompanies the return decision when no period for voluntary departure has been granted or if the obligation to voluntarily leave has not been complied with. One of the reasons for Member States to refrain from granting a period for voluntary departure is the existence of the risk of absconding. Entry bans issued in accordance with the Return Directive are EU-wide and as such should be registered with the Schengen Information System.

Emphasising the needs of Member States, and specifically of those not situated on the external borders of the EU, the European Commission forces us come to the conclusion that the proposal is aimed against those thirdcountry nationals who entered the European Union in an uncontrollable way in 2014/2015 and then disappeared in wealthy Member States, but also against those individuals who registered for international protection but not in the country of first entry. Storing, exchanging and comparing data will certainly improve the return procedure in case such persons are denied any kind of international protection.

The fact that the biometric data of children of at least 6 years of age will be taken and stored in the Eurodac database seems reasonable in the light of the reasons presented by the European Commission: being able to identify them with the help of fingerprints and a facial image will help to further identify them and keep track of their presence in another Member State in case they are missing or separated from their families for 
any other reasons. The same relates to undocumented and unaccompanied minors travelling alone.

The rationale behind the adoption of the period of 5 years for storing the data of persons staying illegally also becomes tolerable, all the more that it serves directly the objective to fight illegal immigration and further secondary movements within EU territory.

That said, the author would like to share her concerns about the proposed instrument. The greatest obstacle to the effectiveness of the EU return policy and relevant national return policies remains the identification of returnees manifested by the lack of cooperation from persons staying illegally, as they conceal their identity or abscond, and the documentation of returnees (issuing return documents) manifested by the lack of cooperation from countries of origin or transit and problems with obtaining the necessary documentation from their consular authorities. It is highly doubtful thus whether a person who entered EU territory undocumented would be able to be re-documented again at any stage of the application of the new Eurodac Regulation. It is also possible that Eurodac will contain even more incorrect personal data provided, whatever the reason, by the undocumented individuals, than it contains today.

The critical remarks have also been expressed by EU bodies and agencies in the framework of their duties arising from EU Treaties.

In the European Data Protection Supervisor's opinion, the retention period of five years is not sufficiently justified, so he expects an additional explanation why such a period is necessary to achieve the new objective of the Eurodac database. At the same time, he recommends the reduction of the data storage period to the actual length of the entry ban issued against a specific individual ${ }^{24}$.

The Meijers Committee contests the justification of the European Commission to extend the objectives of the Eurodac database. Firstly, the secondary movements of persons seeking international protection should not be treated in the same way as irregular migration. Secondly, the EU legislator has already developed other databases to include the objective to fight irregular migration: the Visa Information System, Schengen Information System and Entry/Exit System. The Committee is

24 European Data Protection Supervisor, Opinion 07/2016 EDPS Opinion on the First reform package on the common European Asylum System (Eurodac, EASO and Dublin regulations), 21.9.2016, at p. 7, https:/edps.europa.eu/sites/edp/files/ publication/16-09-21_ceas_opinion_en.pdf (accessed on 30.4.2018). 
of the opinion that SIS serves better the return of irregular migrants as it provides clearer rules on who is to leave EU territory ${ }^{25}$.

For the purposes of combating irregular migration, the Fundamental Rights Agency calls for the blocking of personal data stored on children under the age of 14 years. It also sees the need to add an additional purpose to protect child victims of human trafficking and protect missing children to Article 1 of the Eurodac Regulation. Moreover, it is also desirable to include data concerning family links to increase the possibility to trace and reunite missing family members, especially children ${ }^{26}$.

Disregarding the above it should be emphasised that from the point of view of the developments in the EU return policy the new Eurodac is a desired and valuable instrument, all the more that in the wider context of the refugee crisis these two policies of separate roots and objectives are destined to flawlessly work together. In the opinion of the European Commission a formal link between asylum and return procedures should be achieved in the near future as well as better communication and exchange of information between asylum and return authorities ${ }^{27}$. Eurodac will probably become another "flanking legal instrument" 28 playing an important role in the area of returns, and will be able to bring spectacular effects when connected with other large databases of the Area of Freedom, Security and Justice in the context of their future interoperability.

25 Meijers Committee, Note on the proposed reforms of the Dublin Regulation (COM(2016)197), the Eurodac recast proposal (COM(2016)272 final), and the proposal for an EU Asylum Agency (COM(2016)271 final), at p. 6-7, http://www.commissie-meijers. nl/sites/all/files/cm1609_note.pdf (accessed on 30.4.2018).

26 Fundamental Rights Agency, the impact of the proposal for the revised Eurodac regulation on fundamental rights, 22.12.2016, p. 5, http://fra.europa.eu/en/opinion/2017/ impact-proposal-revised-eurodac-regulation-fundamental-rights (accessed on 30.4.2018).

27 Communication from the Commission to the European Parliament and the Council on a more effective return policy in the European Union - a renewed Action Plan, $\operatorname{COM}(2017) 200$ final, 2.3.2017, at p. 5.

${ }_{28}$ Together with SIS II and VIS, see: Communication from the Commission to the Council and the European Parliament on EU Return Policy, COM(2014)199 final, 28.3.2014, at p. 4. 


\section{Bibliography}

1. European Data Protection Supervisor, Opinion 07/2016 EDPS Opinion on the First reform package on the common European Asylum System (Eurodac, EASO and Dublin regulations), 21.9.2016, https://edps.europa. eu/sites/edp/files/publication/16-09-21_ceas_opinion_en.pdf.

2. Fundamental Rights Agency, the impact of the proposal for the revised Eurodac regulation on fundamental rights, 22.12.2016, http://fra.europa.eu/en/opinion/2017/impact -proposal-revised-eurodac-regulation-fundamental-rights.

3. Meijers Committee, Note on the proposed reforms of the Dublin Regulation (COM(2016)197), the Eurodac recast proposal (COM(2016)272 final), and the proposal for an EU Asylum Agency (COM(2016)271 final), http://www. commissie-meijers.nl/sites/all/files/cm1609_note.pdf.

4. Ch. Vincent, Looking Beyond the Rhetoric of the Refugee Crisis: The Failed Reform of the Common European Asylum System, "European Journal of Human Rights" 2016, no5. 